\title{
Membandingkan Keefektifan Model Pembelajaran Tipe Jigsaw dan Tipe Diskusi Panel untuk Meningkatkan Hasil Belajar Mahasiswa dalam Mempelajari Kimia Organik
}

\author{
Sigit Hadiantoro ${ }^{1}$ \\ ${ }^{1}$ Pendidikan Kimia-Universitas Negeri Malang
}

\section{INFO ARTIKEL}

\section{Riwayat Artikel:}

Diterima: 17 juni 2019

Disetujui: 14 Oktober 2019

\section{Kata kunci:}

Tipe jigsaw

Diskusi panel

Hasil belajar

Analisis variansi

\author{
Alamat Korespondensi: \\ Sigit Hadiantoro \\ Pendidikan Kimia \\ Pascasarjana Universitas Negeri Malang \\ Jalan Semarang 5, Malang 65154 \\ E-mail: hadiantoro.sigit@gmail.com
}

\section{ABSTRAK}

\begin{abstract}
The aim of this study is to find out the effectiveness differences of jigsaw cooperative learning model compare with panel discussion to increase student's academic achievement in organic chemistry learning. The effectiveness was determined by learning achievement in organic chemistry. The research design was quasi experiment with nonequivalent pretestposttest. Statistical analysis by Anova shows that there are significant differences between learning methods to increased academic achievement. No significant differences between learning sources, also between interactions. One tail t-test show that, in this study, panel discussion learning is better than jigsaw learning to increase student's learning achievement in organic chemistry reactions.
\end{abstract}

\begin{abstract}
Abstrak: Penelitian ini bertujuan untuk mengetahui apakah ada perbedaan hasil belajar pada mahasiswa yang belajar dengan menggunakan pembelajaran kooperatif tipe jigsaw dan pembelajaran kooperatif tipe diskusi panel dalam mempelajari reaksi kimia organik. Penelitian ini menggunakan metode kuantitatif eksperimen semu (quasi experiment) dengan model prates-pascates kelompok-kelompok tak setara. Analisis Variansi dua jalur menunjukkan bahwa ada perbedaan yang nyata di antara kedua metode pembelajatan yang digunakan, sedangkan kedua sumber belajar tidak menunjukkan adanya perbedaan yang nyata. Dari ujit satu ekor terlihat bahwa untuk meningkatkan hasil belajar mahasiswa dalam mempelajari reaksi-reaksi kimia organik pembelajaran tipe diskusi panel lebih efektif daripada tipe jigsaw.
\end{abstract}

Pembelajaran kooperatif dirancang untuk membangkitkan kerjasama dan interaksi kelompok di antara siswa. Strategi ini dirancang untuk mengeliminasi persaingan yang dijumpai dalam sebagian besar kelas (Slavin, 2008). Pembelajaran kooperatif mendorong siswa bekerja bersama dan saling membantu untuk mencapai tujuan bersama, karenanya mereka menemukan keberhasilan dalam membangkitkan sikap antar kelompok yang positif dalam kelas yang multikultur. Pembelajaran kooperatif memungkinkan siswa berperan aktif sebagai anggota kelompok dalam usaha mencapai tujuan pengajaran.

Teori belajar yang mendukung pembelajaran kooperatif adalah teori belajar sosial (social learning) dari (Vygotsky, 1994) yang menyatakan bahwa kemampuan kognitif siswa akan lebih meningkat dalam belajar kelompok daripada bila belajar secara individu.

Pandangan konstruktivis merupakan suatu filosofis yang mendasari belajar kooperatif sebagaimana filsafat pengetahuan menekankan bahwa pengetahuan kita adalah suatu konstruksi (bentukan) kita sendiri (Suparno, 
1997). Selanjutnya menurut (Jacobsen, Eggen, \& Kauchak, 2009)karakteristik konstruktivis adalah pebelajar dapat mengkonstruksi sendiri pemahamannya dan belajar dengan difasilitasi oleh interaksi sosial. Jadi pandangan konstruktivisme yang menjadi landasan filosofis pembelajaran kooperatif berpengang pada asumsi bahwa pengetahuan diperoleh sebagai akibat dari proses konstruksi yang terus menerus diterima. Pengalaman-pengalaman diatur, disusun dan ditata kembali dengan mengaitkan struktur kognitif yang dimiliki siswa, sedikit demi sedikit dimodifikasi dan dikembangkan. Pengetahuan akan diciptakan dalam pikiran siswa sebagai hasil dari interaksi panca indera dengan lingkungan.

Menurut (Ghazali, 2009) ciri kelas yang mengunakan pendekatan kooperatif adalah 1) guru akan selalu menciptakan kelas yang dapat membuat siswa berinteraksi, 2) kelas selalu didorong untuk bekerjasama antara siswa dan munculnya inisiatif bekerjasama tersebut mendapat penghargaan, 3) memberikan kesadaran kepada siswa bahwa yang dipelajari bukanlah sesuatu yang berdiri sendiri, memberikan ruang kepada siswa yang suka melakukan sesuatu yang beresiko, misalnya memberikan suatu tugas yang penuh tantangan, dan 5) suasana kreatif siswa diupayakan tercipta di dalam kelas.

Kelebihan belajar kooperatif menurut (Hill \& Hill, 1993) sebagai berikut : 1) Meningkatkan prestasi siswa, 2) memperdalam pemahaman siswa, 3) me-nyenangkan siswa, 4) mengembangkan sikap kepemimpinan, 5) mengembangkan sikap positif siswa, 6) mengembangkan sikap menghargai diri sendiri, 7) membuat belajar secara bersama dan saling bertanggung jawab, 8) mengembangkan rasa saling memiliki dan 9) mengembangkan ketrampilan untuk masa depan.

Salah satu jenis pembelajaran kooperatif adalah pembelajaran kooperatif tipe jigsaw. Belajar kooperatif tipe jigsaw ini untuk memperkaya pengalaman siswa dalam menyelesaikan masalah yang dilakukan secara kelompok. Disamping itu yang menonjol dari model ini yaitu adanya kerjasama dalam kelompok ahli dan kelompok kooperatif untuk mempelajari atau memahami suatu materi yang berbeda-beda. Belajar koopratif tipe jigsaw menuntut siswa agar dapat mengembangkan daya pikir, daya inisiatif dan kreatif sesuai dengan karakteristik ilmu kimia. Sebagaimana dinyatakan (Djamarah \& Zain, 2010) bahwa siswa dapat mengembangkan daya pikir, daya inisiatif, tanggung jawab dan melatih diri sendiri. Selain itu dengan model belajar kooperatif siswa mempunyai kebebasan untuk bertanya kepada teman kelompoknya karena umumnya siswa enggan bertanya kepada guru sebagai pembimbing pada saat ia mendapat kesulitan dalam memahami suatu materi.

Dengan pembelajaran tipe jigsaw siswa dituntut untuk dapat menguasai salah satu sub pokok bahasan kemudian mengajarkannya pada teman sekelompoknya. Menurut (Nunan, 1999)dalam Wikipedia belajar dengan cara mengajar (learning by teaching) mempunyai beberapa keuntungan, antara lain: siswa lebih termotivasi, siswa belajar lebih efisien, dan lebih aktif, sehingga akan meningkatkan penguasaan konsep.

Pada pembelajaran tipe jigsaw kelas dibagi menjadi beberapa kelompok kecil ( $3-5$ orang) dengan karakteristik yang heterogen. Bahan ajar diberikan kepada siswa dalam bentuk teks dan tiap-tiap siswa bertanggung jawab untuk mempelajari bagian dari bahan ajar tersebut. Para anggota tiap-tiap kelompok yang berbeda yang bertanggung jawab untuk mempelajari bagian bahan ajar yang sama dikumpulkan untuk saling membantu dalam mempelajari bagian bahan ajar tersebut. Kelompok ini disebut kelompok pakar. Selanjutnya masing-masing siswa dalam kelompok pakar masing-masing kembali ke kelompok semula untuk mengajar anggota lain mengenai materi yang telah dipelajari dalam kelompok pakar. Jadi pembelajaran kooperatif tipe jigsaw sangat baik dilakukan pada pokok bahasan yang memiliki beberapa sub pokok bahasan yang tidak saling berurutan.

Penelitian tentang model pembelajaran tipe jigsaw yang telah ada sebagian besar membandingkan model ini dengan model pembelajaran konvensional (Kilic, 2008). Beberapa penelitian membendingkannya dengan model pembelajaran kooperatif tipe STAD. Pada penelitian ini model pembelajaran kooperatif tipe jigsaw dibandingkan dengan pembelajaran tipe diskusi panel untuk mengetahui mana yang lebi efektif antara kedua tipe pembelajaran tersebut.

Pada penelitian ini pembelajaran tipe jigsaw dilakukan sesuai dengan sepuluh langkah yang dikemukakan oleh (Aronson, 2002). Sedangkan fase-fase belajar pada tipe jigsaw dibahas berdasarkan tahapan yang dikemukakan oleh (Johnson \& Johnson, 1991)

Ada beberapa kelebihan dari kelas jigsaw, di antaranya: mudah dipelajari oleh pengajar, dapat digunakan bersama dengan strategi mengajar yang lain, dapat efektif walaupun hanya dilakukan selama satu jam sehari. Beberapa kendala pada penggunaan kelas jigsaw di antaranya adanya mahasiswa yang terlalu dominan. Untuk mengurangi masalah ini, pada tiap kelompok asal (jigsaw) perlu ditunjuk satu orang sebagai ketua 
kelompok. Ketua kelompok bertanggung jawab agar setiap anggota kelompok berpartisipasi secara aktif dan merata dalam berdiskusi. Mahasiswa menyadari bahwa kelompok akan lebih efektif jika masing-masing mahasiswa diberi kesempatan untuk menjelaskan materinya sebelum diajukan pertanyaan-pertanyaan dan tanggapan. Masalah lain adalah adanya mahasiswa yang lambat dalam kelompok. Untuk mengatasi hal ini pada teknik jigsaw dibentuk kelompok "pakar". Mahasiswa bekerja dengan yang lain dari kelompok asal yang lain untuk membahas bagian pelajaran yang sama.

Mahasiswa yang pandai perlu didorong untuk mengembangkan pemikiran pengajar karena posisi ini dapat menjadi tantangan. Masalah juga timbul pada mahasiswa yang terbiasa dengan suasana persaingan. Sasaran dari kelas jigsaw adalah pengurangan persaingan dan meningkatkan kerjasama, sehingga mahasiswa kompetitif dapat menimbulkan kesulitan.

Model pembelajaran yang sering digunakan dalam kelas sebagai variasi disamping model konvensional ialah diskusi panel. Diskusi panel sangat bermanfaat jika mahasiswa diminta untuk menyampaikan presentasi atau laporan di depan kelas. Kelompok-kelompok mahasiswa suatu topik untuk dipelajari dan diminta untuk mempersiapkan makalah untuk presentasi. Masing-masing panelis menjelaskan secara singkat makalahnya sebelum diskusi dilakukan dengan pertanyaan-pertanyaan dari audiens. Kunci sukses diskusi panel adalah memilih topik secara cermat dan memberikan arahan yang cukup pada mahasoswa untuk memastikan bahwa mereka dapat mempersiapkan dengan baik presentasinya. Kelas juga harus disiapkan dengan memberikan aturan-aturan yang harus dipatuhi. Pada implementasinya pembelajaran tipe diskusi panel dapat dikombinasikan dengan pembelajaran tipe jigsaw,

Dalam mempelajari suatu materi banyak sumber yang dapat digali. Salah satu sumber belajar yang saat ini sangat mudah untuk didapatkan adalah melalui media internet. Penggunaan internet sebagai sumber belajar dapat melengkapi keterbatasan pustaka yang tersedia di perpustakaan. Namun penggunaan internet sebagai sumber belajar harus melalui pemilihan yang cermat karena internet merupakan forum terbuka yang dapat diakses siapa saja untuk mencantumkan artikel atau bahan belajar. Sifat terbuka dari internet ini memungkinkan terjadinya kasalahan pemahaman ataupun kesalahan kinsep. Oleh karena itu penggunaan internet sebagai sumber belajar bagi mahasiswa perlu melibatkan pengajar untuk memilih dan memilah sumber belajar yang valid.

\section{METODE}

\section{Rancangan Penelitian}

Penelitian ini merupakan penelitian eksperimen semu dengan model rancangan pretest-posttest kelompokkelompok tak setara (Ibnu, Mukhadis, \& Dasna, 2003)). Keempat kelompok mendapatkan materi ajar yang sama perbedaan antara keempat kelompok tersebut adalah pada metode pembelajaranjaran dan sumber bahan ajar. Rancangan penelitian disajikan dalam Tabel 1.

Tabel 1 Rancangan penelitian

\begin{tabular}{cccc}
\hline Kelompok & Pretest & Perlakuan & Posttest \\
\hline E1 & O1 & X1 & O5 \\
E2 & O2 & X2 & O6 \\
E3 & O3 & X3 & O7 \\
E4 & O4 & X4 & O8 \\
\hline
\end{tabular}

Keterangan:

X1: Jigsaw ; sumber belajar tambahan dari Internet

X2: Diskusi Panel ; sumber belajar tambahan dari Internet

X3: Jigsaw ; sumber belajar : Buku Teks

X2: Diskusi Panel ; sumber belajar: Buku Teks

\section{Populasi dan Sampel Penelitian}

Pada semester genap tahun akademik 2008/2009 Jurusan Teknik Kimia Politeknik Negeri Malang mempunyai sekitar 300 orang mahasiswa yang terdiri dari 12 kelas. Dari kelas-kelas tersebut digunakan empat kelas sebagai sample dalam penelitian ini, yaitu mahasiswa tahun pertama angkatan tahun 2008. Masing masing kelas terdiri dari 24 - 26 orang mahasiswa. 
Tabel 2 Komposisi Mahasiswa Laki-laki dan Perempuan angkatan tahun 2008

\begin{tabular}{cccc}
\hline Kelas & \multicolumn{3}{c}{ Jumlah mahasiswa } \\
& Laki-laki & Perempuan & Total \\
\hline 1-A & 7 & 19 & 26 \\
1-B & 9 & 17 & 26 \\
1-C & 6 & 18 & 24 \\
1-D & 6 & 20 & 26 \\
\hline
\end{tabular}

Dari empat kelas tersebut masing-masing kelas melakukan pembelajaran berikut.

a. Pembelajaran tipe jigsaw dengan sumber belajar dari internet. (1-C).

b. Pembelajaran tipe jigsaw dengan sumber belajar nuku teks. (1-D).

c. Pembelajaran tipe diskusi panel dengan sumber belajar dari internet (1-A).

d. Pembelajaran tipe diskusi panel dengan sumber belajar buku teks. (1-B)

\section{Variabel Penelitian}

Variabel-variabel yang digunakan dalam penelitian ini yaitu, a) Variabel bebas yang digunakan dalam penelitian ini adalah metode pembelajaran dan sumber belajar. Variasi metode pembelajaran terdiri dari model pembelajaran kooperatif tipe jigsaw dan model pembelajaran kooperatif tipe diskusi panel di depan kelas. Sumber belajar divariasi dengan bahan ajar dari buku teks dan bahan ajar dari internet, b) Sebagai kovariabelnya adalah kemampuan awal mahasiswa tentang reaksi-reaksi Kimia Organik, c) Variabel kontrol dalam penelitian ini adalah pengajar yang bertindak sebagai nara sumber dan lamanya waktu yang digunakan untuk pembelajaran, d) Variabel terikatnya adalah hasil belajar mahasiswa tentang reaksi-reaksi Kimia Organik.

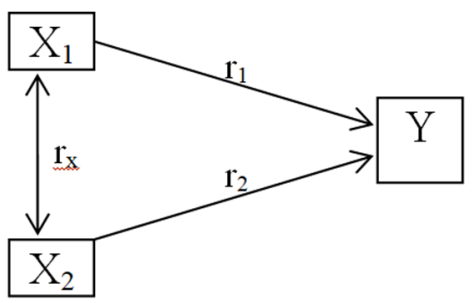

Gambar 1 Variabel Penelitian

$\mathrm{X}_{1} \quad$ : Metode Pembelajaran

$\mathrm{X}_{1} \quad$ : Sumber Belajar

Y : Hasil Belajar Mahasiswa

\section{Instrumen Penelitian}

Instrumen yang digunakan dalam penelitian ini meliputi:

a. Langkah-langkah pembelajaran tipe Jigsaw, digunakan sebagai panduan bagi dosen untuk melaksanakan pembelajaran kooperatif tipe Jigsaw. Pengaturan kelas pada diskusi dalam kelompok asal sebagaimana terlihat pada Gbr 2. Untuk diskusi dalam kelompok pakar, kelas diatur sebagaimana terlihat pada Gbr 3.

b. Langkah-langkah pembelajaran diskusi panel, digunakan sebagai panduan bagi dosen untuk melaksanakan pembelajaran diskusi panel. Pengaturan kelas pada diskusi panel adalah sebagaimana terlihat pada Gbr 4.

c. Bahan ajar yang digunakan berisi materi yang membahas reaksi-reaksi kimia organik, meliputi reaksi adisi elektrofilik, adisi elektrofilik, substitusi elektrofilik, dan substitusi nukleofilik. Sebagai sumber bahan ajar adalah internet atau buku teks.

d. Tes yang diujikan pada mahasiswa terdiri dari 24 soal pilihan ganda, dipilih dari 40 butir soal yang telah divalidasi dengan tingkat validitas $96.9 \%$ dan telah diujicobakan pada mahasiswa tahun sebelumnya (angkatan 2007/2008). Soal-soal tersebut mencakup keempat pokok bahasan yang dipelajari dengan tingkat kesukaran yang bervariasi.. 


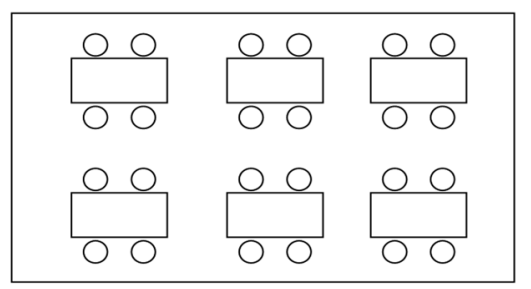

Gambar 2. Pengaturan Kelas untuk Diskusi dalam Kelompok Asal

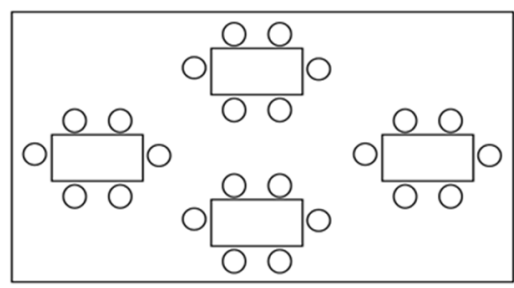

Gambar 3. Pengaturan Kelas untuk Diskusi dalam Kelompok Pakar

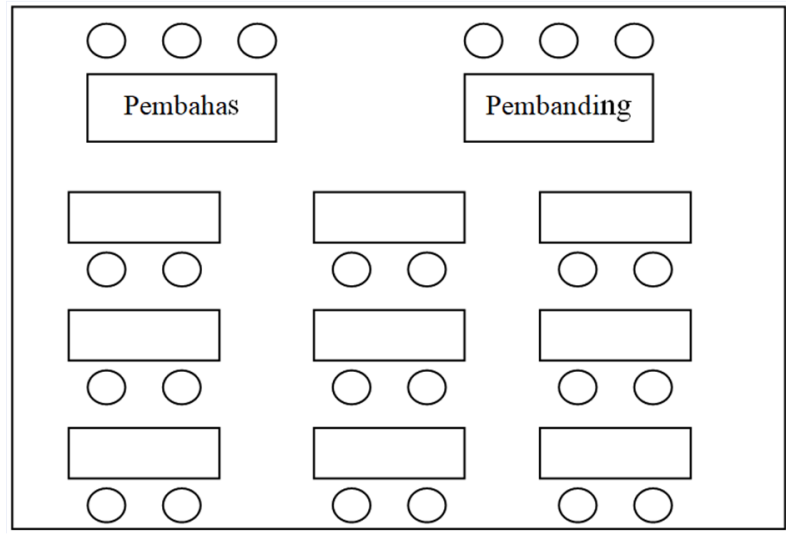

Gambar 4 Pengaturan kelas pada diskusi panel

\section{Analisis Data}

Untuk mengetahui perbedaan keefektifan digunakan Anava dua jalur. Sedangkan untuk mengetahui manakah yang lebih efektif antara model pembelajaran kooperatif tipe jigsaw dengan tipe diskusi panel terhadap hasil belajar mahasiswa digunakan analisis uji-t satu ekor.

\section{HASIL}

Hasil Prates dan Pascates mahasiswa dalam menjawab soal-soal pilihan ganda reaksi kimia organik dicantumkan pada Tabel 3 .

Tabel 3. Deskripsi Nilai Prates dan Pascates Mahasiswa

\begin{tabular}{|c|c|c|c|c|c|c|c|c|}
\hline \multirow[t]{3}{*}{ Deskripsi } & \multicolumn{8}{|c|}{ Kelas } \\
\hline & \multicolumn{2}{|c|}{ 1A (D-I) } & \multicolumn{2}{|c|}{ 1B (D-B) } & \multicolumn{2}{|c|}{ 1C (J-I) } & \multicolumn{2}{|c|}{ 1D (J-B) } \\
\hline & Prates & Pasca & Prates & Pasca & Prates & Pasca & Prates & Pasca \\
\hline Rera & 20.0 & 50.4 & 23.5 & 56.3 & 22.6 & 33.8 & 21.3 & 32.5 \\
\hline Maksi & 41.7 & 62.5 & 1.7 & 75.0 & 37.5 & 50.0 & 29.2 & 50.0 \\
\hline Mini & 4.2 & 25. & . & 33.3 & 12.5 & 16. & 8.3 & 16.7 \\
\hline Variansi & 132.9 & 81.0 & 63.8 & 223.9 & 49.7 & 68.4 & 29.8 & 92.6 \\
\hline F-hitung & \multicolumn{2}{|c|}{1.64} & \multicolumn{2}{|c|}{3.51} & \multicolumn{2}{|c|}{1.38} & \multicolumn{2}{|c|}{3.11} \\
\hline
\end{tabular}

Peningkatan nilai yang dicapai oleh mahasiswa disajikan dalam Tabel 4. 
Tabel 4. Peningkatan Hasil Belajar Mahasiswa

\begin{tabular}{ccccc}
\hline & \multicolumn{4}{c}{ Kelas } \\
Deskripsi & 1A (D-I) & 1B (D-B) & 1C (J-I) & 1D (J-B) \\
\hline Rerata & 30.4 & 32.5 & 11.3 & 11.7 \\
Maksimum & 54.2 & 58.3 & 33.3 & 37.5 \\
Minimum & 4.2 & 0.0 & -8.3 & -12.5 \\
Derajat Kebebasan & 25 & 25 & 23 & 25 \\
Variansi & 170.2 & 369.0 & 110.9 & 154.2 \\
\hline
\end{tabular}

Hasil analisis menggunakan Anava dirangkum dalam Tabel 5

Tabel 5. Rangkuman Perhitungan Anava Dua Jalur

\begin{tabular}{ccccc}
\hline \multicolumn{2}{c}{ Nilai Pascates } & \multicolumn{2}{c}{ Peningkatan Nilai } & F - tabel \\
\hline \multicolumn{4}{c}{ F - hitung } & F - hitung \\
FA & 0.843 & FA & 0.133 & $3,94(\alpha=0,05)$ \\
FB & 87.792 & FB & 50.196 & $6,90(\alpha=0,01)$ \\
FAB & 2.983 & FAB & 0.248 & \\
\hline
\end{tabular}

Uji-t satu ekor untuk kedua metode pembelajaran yang digunakan dicasntumkan dalam Tabel 6.

Tabel 6. Uji-t Satu Ekor tehadap Peningkatan Nilai Tes antara Kelas Jigsaw dan Kelas Diskusi dengan Sumber Belajar yang Sama

\begin{tabular}{ccccc}
\hline Kelas & Rerata & t - hitung & db & t - tabel \\
\hline 1-A & 30.3 & \multirow{2}{*}{5.576} & \multirow{2}{*}{48} & 2.012 \\
1-C & 11.5 & & & \\
1-B & 32.7 & 4.680 & 50 & 2.015 \\
1-D & 11.7 & & & \\
\hline
\end{tabular}

\section{PEMBAHASAN}

Model pembelajaran kooperatif tidak terlepas dari kelemahan di samping kekuatan yang ada padanya. Kelemahan tersebut antara lain terkait dengan kesiapan dosen dan mahasiswa untuk terlibat dalam suatu strategi pembelajaran yang memang berbeda dengan pembelajaran yang selama ini diterapkan. Dosen yang terbiasa memberikan semua materi kepada para mahasiswanya, mungkin memerlukan waktu untuk dapat secara berangsur-angsur mengubah kebiasaan tersebut. Ketidaksiapan dosen untuk mengelola pembelajaran demikian dapat diatasi dengan cara pemberian pelatihan yang kemudian disertai dengan kemauan yang kuat untuk mencobakannya. Sementara itu, ketidaksiapan mahasiswa dapat diatasi dengan cara menyediakan panduan yang antara lain memuat cara kerja yang jelas, petunjuk tentang sumber yang dapat dieksplorasi, serta deskripsi tentang hasil akhir yang diharapkan, system evaluasi, dan sebagainya.

Kendala lain adalah waktu. Strategi pembelajaran kooperatif memerlukan waktu yang cukup panjang dan fleksibel, meskipun untuk topik-topik tertentu waktu yang diperlukan mungkin cukup dua kali tatap muka ditambah dengan kegiatan-kegiatan di luar jam pelajaran.

Terlepas dari kelemahannya, model pembelajaran kooperatif mempunyai kekuatan dalam mengembangkan softskills mahasiswa seperti, kemampuan berkomunikasi, berfikir kritis, bertanggung jawab, serta bekerja sama. Jika kelemahan dapat diminimalkan, maka kekuatan model ini akan membuahkan proses dan hasil belajar yang dapat memacu peningkatan potensi mahasiswa secara optimal. Oleh sebab itu, sangat diharapkan dosen mencoba menerapkan model pembelajaran kooperatif. Dosen dapat mengembangkan model ini sesuai dengan bidang studinya, bahkan mungkin dari model ini para dosen dapat mengembangkan model lain yang lebih meyakinkan.

\section{Tahapan pembelajaran kooperatif tipe jigsaw}

Sebelum melaksanakan pembelajaran, dosen melakukan review pada mahasiswa berkaitan dengan konsepkonsep yang harus dikuasai sehingga mahasiswa dapat menghubungkan konsep yang telah dipelajari dengan konsep yang sedang dibahas.: 
a. Fase pengaturan (setting up phase). Pada fase ini mahasiswa dipersiapkan untuk dapat belajar dalam kelompok. Pembagian tugas untuk mempelajari salah satu sub pokok bahasan akan melibatkan mahasiswa dalam negosiasi untuk memilih sub pokok bahasan yang dipelajarinya. Pada saat mencari bahan belajar seharusnya mahasiswa sudah membaca materi yang digunakan untuk berdiskusi dalam kelompok pakar. Kendala yang dijumpai mahasiswa pada fase ini adalah memilih bahan belajar yang tepat, terutama bahan belajar dari internet. Dalam hal ini perlu keterlibatan pengajar untuk memeriksa sumber belajar yang dimiliki oleh mahasiswa.

b. Fase pembentukan pakar (creating expert phase). Pada diskusi kelompok pakar masing masing anggota mengemukakan hasil belajarnya tentang reaksi kimia organik yang telah dipelajarinya. Jika ada perbedaan hasil belajar di antara anggota kelompok, misalnya cara menggambarkan struktur molekul, dosen memberikan penjelasan mengenai cara mana yang benar. Fase ini diperlukan untuk membentuk 'pakar' pada salah satu sub pokok bahasan reaksi kimia organik.

c. Fase penyusunan ulang tugas (task recomposition phase). Pada fase ini disamping menguasai salah satu konsep reaksi kimia organik, mahasiswa juga dituntut untuk mampu menjelaskan konsep tersebut agar anggota-amggota lain dalam kelompoknya dapat memahaminya. Nampaknya tidak semua mahasiswa yang terlibat dalam pembelajaran ini memenuhi persyaratan tersebut.

d. Fase penilaian (assessment phase). Penilaian terhadap hasil belajar pokok bahasan reaksi kimia organik pada kelompok jigsaw menunjukkan bahwa hasil belajar mahasiswa masih kurang. Ketiga fase di atas mempunyai kemungkinan sebagai penyebab kurangnya hasil belajar mahasiswa, misalnya: (1) pada fase pertama mahasiswa tidak mempelajari dengan benar tugas yang diberikan kepadanya, tidak dapat menghubungkan pengetahuan awal yang dimilikinya, atau bahkan tidak menguasai konsep prasyarat yang diperlukan; (2) fase kedua seharusnya dapat mengatasi kekurangan pada fase pertama dengan disediakan waktu yang lebih panjang. Proses diskusi pada kelompok 'pakar' tidak dapat berlangsung secara baik jika sebagian besar anggota kelompok tidak mempersiapkan diri; (3) kelemahan yang ada pada fase ketiga terjadi karena kurangnya kemampuan mahasiswa dalam menjelaskan atau mengajarkan pengetahuannya kepada anggota kelompok yang lain.

\section{Hasil belajar mahasiswa}

Dari nilai rata-rata prates yang tercantum pada Tabel 3 dapat diketahui bahwa kemampuan awal mahasiswa tentang reaksi-reaksi kimia organik masih sangat kurang. Hal ini disebabkan oleh latar belakang dari mahasiswa yang berasal dari berbagai sekolah menengah atas dengan pelajaran kimia organik yang tidak diberikan secara mendalam.

Pada Peningkatan nilai tes F-A dan F-B menunjukkan hal yang sama dengan F-A dan F-B pada nilai pascates, dengan nilai F-B sebesar 50.2 yang lebih besar dari F-hitung. Namun untuk F-AB menunjukkan sedikit perbedaan.

Untuk mengetahui kelompok/kelas mana yang lebih baik, maka dilakukan Uji-t terhadap peningkatan nilai tes. Analisis dengan Uji-t menunjukkan bahwa untuk meningkatkan hasil belajar mahasiswa mahasiswa tentang mekanisme reaksi senyawa organik,

Analisis statistik Anava dua jalur dan Uji-t satu ekor menunjukkan bahwa pembelajaran kooperatif tipe diskusi panel dengan sumber bahan ajar dari buku teks maupun dari internet menunjukkan hasil yang lebih baik daripada pembelajaran kooperatif tipe jigsaw.

Ada beberapa hal yang diduga menyebabkan rendahnya hasil belajar mahasiswa dalam kelas jigsaw yaitu:

a. Dalam kelompok pakar, pada waktu diskusi untuk membahas salah satu bagian dari materi yang dipelajari kelompok pakar kurang optimal memanfaatkan nara sumber. Misalnya pada saat salah satu menemui hal-hal yang tidak dipahami, kelompok ini menanyakan kepada narasumber untuk mendapatkan penjelasan. Penjelasan ini tentu saja tidak perlu didengar oleh kelompok lain, karena akan mengganggu konsentrasi dalam mempelajari pokok bahasan yang menjadi tugasnya.

b. Dalam kelompok asal, kesulitan yang dialami oleh mahasiswa dalam kelompok asal adalah mengkomunikasikan hasil pembahasan yang dilakukannya dalam kelompok pakar. Hal ini dapt disebabkan karena mahasiswa kurang/belum menguasai materi yang harus disampaikan atau tidak dapat mengungkapkan hasil yang telah dipelajarinya kepada anggota kelompok yang lain.

Hal ini tidak terjadi pada kelas diskusi panel. Pada kelas ini secara bergantian helompok-kelompok menjelaskan pokok bahasan yang dipelajarinya di depan kelas. Bila ada permasalahan narasumber 
memberikan penjelasan yang diperlukan atau melakukan koreksi bila ada kesalahan C1-C3. Penjelasan dari narasumber didengarkan oleh seluruh mahasiswa dalam kelas tersebut. Faktor ini yang mungkin menjadi penyebab hasil belajar mahasiswa pada kelas diskusi panel relatif lebih tinggi daripada hasil belajar mahasiswa pada kelas jigsaw.

Faktor lain yang menyebabkan rendahnya nilai dari kelompok jigsaw adalah komunikasi untuk mengajarkan konsep yang telah dipelajarinya kepada teman sekelompoknya tidak berlangsung dengan baik. Di ssamping itu kemampuan mahasiswa untuk menguasai konsep masih sangat kurang. Beberapa penelitian menunjukkan bahwa model pembelajaran kooperatif tipe jigsaw mempunyai keefektifan yang lebih baik dari model pembelajaran yang lain. Tetapi di antara penelitian-penelitian tersebut tidak ada yang membandingkan model pembelajaran kooperatif tipe jigsaw dengan tipe diskusi panel. Pada umumnya pembandingan dilakukan terhadap model pembelajaran konvensional atau model pembelajaran kooperatif yang lain.

Disamping itu ada kemungkinan bahwa mahasiswa baru mengenal model pembelajaran tipe jigsaw untuk pertamakalinya sehingga belum terbiasa. Sedangkan model pembelajaran tipe diskusi panel sudah sering dilakukan oleh mahasiswa Jurusan Teknik Kimia Polinema. (Paulson, 1999) dalam penelitiannya mengemukakan bahwa pembelajaran kooperatif akan berhasil dengan baik jika perubahan model pembelajaran dilakukan secara bertahap.

Hasil penelitian menunjukkan bahwa tidak ada perbedaan yang nyata pada hasil belajar dengan menggunakan sumber belajar dari buku teks maupun sumber belajar dari internet. Nampaknya meskipun dari internet dapat diperoleh gambar-gambar model molekul dan animasi untuk menjelaskan reaksi kimia organik, mahasiswa tidak dapat memanfaatkannya secara maksimal untuk memahami materi yang dipelajarinya. Sebagaimana yang dikemukakan oleh (Herron \& Nurrenbern, 1999) dalam Journal of Chemical Education, bahwa dalam mempelajari ilmu kimia diperlukan cara konstruktivisme pada konsep tertentu dan cara belajar perilaku pada konsep yang lain. Dengan model pembelajaran kooperatif tipe jigsaw mahasiswa dituntut untuk mampu mengkonstruk pengetahuannya sendiri. Tetapi pada konsep-konsep yang baru dikenal perlu bimbingan pengajar untuk memahami konsep tersebut.

\section{SIMPULAN DAN SARAN}

\section{Simpulan}

Dari hasil penelitian dan pembahasan yang telah dilakukan dapat ditarik beberapa kesimpulan: Perhitungan analisis variansi untuk peningkatan nilai menghasilkan nilai F-hitung antar metode pembelajaran sebesar 50,20 > F-tabel, menunjukkan adanya perbedaan antar metode pembelajaran. F-hitung antar sumber belajar sebesar 0,13 < F-tabel. Sedangkan interaksi antara metode pembelajaran dengan sumber belajar mempunyai F-hitung sebesar $0,25<$ F-tabel.

Uji-t satu ekor terhadap nilai mahasiswa pada pascates-prates menghasilkan kesimpulan sebagai berikut:

a. Terdapat perbedaan yang nyata antara pembelajaran tipe jigsaw dengan tipe diskusi panel pada hasil belajar mahasiswa dalam mempelajari reaksi-reaksi kimia organik.

b. Tidak terdapat perbedaan yang nyata antara buku teks dan internet sebagai sumber belajar pada hasil belajar mahasiswa dalam mempelajari reaksi-reaksi kimia organik.

c. Tidak terdapat perbedaan yang nyata antar interaksi metode pembelajaran dengan sumber belajar pada hasil belajar mahasiswa dalam mempelajari reaksi-reaksi kimia organik.

d. Dengan menggunakan bahan ajar buku teks, pembelajaran tipe diskusi panel lebih baik daripada pembelajaran kooperatif tipe jigsaw dalam meningkatkan hasil belajar mahasiswa dalam mempelajari reaksi-reaksi kimia organik. T-hitung $(4,68)>$ t-tabel $(2,06)$

e. Dengan menggunakan bahan ajar buku dari internet, pembelajaran tipe diskusi panel lebih baik daripada pembelajaran tipe jigsaw dalam meningkatkan hasil belajar mahasiswa dalam mempelajari reaksi-reaksi kimia organik. , T-hitung $(5,58)>$ t-tabel $(2,06)$

\section{Saran}

Untuk melaksanakan model pembelajaran kooperatif tipe jigsaw diperlukan peranan yang lebih besar dari pengajar dengan strategi pembelajaran yang tepat. Pembelajaran kooperatif tipe jigsaw memerlukan waktu yang relatif lebih banyak dapipada pembelajaran konvensional. Pemberian motivasi perlu dilakukan secara 
terus-menerus agar mahasiswa menyadari pentingnya materi kimia organik untuk mempelajari matakuliah di semester berikutnya. Perlu diteliti korelasi antara penguasaan bahasa inggris dengan pemahaman konsep bagi kelompok dengan bahan ajar dari internet

\section{DAFTAR PUSTAKA}

Aronson, E. (2002). Building empathy, compassion, and achievement in the jigsaw classroom. In Improving academic achievement (pp. 209-225). Elsevier.

Djamarah, S. B., \& Zain, A. (2010). Strategi Belajar Mengajar Jakarta: Rineka Cipta.

Ghazali, A. S. (2009). Menerapkan Paradigma Konstruktivisme melalui Strategi Belajar Kooperatif dalam Pembelajaran Bahasa. Jurnal Pendidikan Dan Pembelajaran (JPP), 9(2).

Herron, J. D., \& Nurrenbern, S. C. (1999). Chemical education research: Improving chemistry learning. Journal of Chemical Education, 76(10), 1353.

Hill, S., \& Hill, T. (1993). The Cooperative Classroom (A guide to Cooperative Learning) Australia. Eleanor Curtain publishing.

Ibnu, S., Mukhadis, A., \& Dasna, I. W. (2003). Dasar-dasar metodologi Penelitian. Malang.

Jacobsen, D. A., Eggen, P., \& Kauchak, D. (2009). Methods For Teaching Metode-metode Pengajaran Meningkatkan belajar siswa TK-SMA. Yogyakarta: Pustaka Pelajar.

Johnson, D. W., \& Johnson, R. T. (1991). Learning together and alone: Cooperative, competitive, and individualistic learning. Prentice-Hall, Inc.

Kilic, D. (2008). The effect of the Jigsaw technique on learning the concepts of the principles and methods of teaching. World Applied Sciences Journal, 4(1), 109-114.

Nunan, D. (1999). Second Language Teaching \& Learning. Heinle Publishers.

Paulson, D. R. (1999). Active learning and cooperative learning in the organic chemistry lecture class. Journal of Chemical Education, 76(8), 1136.

Slavin, R. E. (2008). Cooperative learning, success for all, and evidence-based reform in education. Éducation et Didactique, $2(2), 149-157$.

Suparno, P. (1997). Filsafat konstruktivisme dalam pendidikan. Yogyakarta: Kanisius.

Vygotsky, L. S. (1994). The problem of the environment. The Vygotsky Reader, 338-354. 